\title{
Climatic Conditions and Vertical Zonality of Soil Distribution in South Yunnan, China
}

\author{
Kazuko UruShibara-Yoshino* and Shizuo NaGATSUKA**
}

\begin{abstract}
In Xishuangbanna, Yunnan Province, zonal soils are vertically distributed as follows: Quasi latosol (below $600 \mathrm{~m}$ a.s.1.), Lateritic red earth $(600-900 \mathrm{~m}$ a.s.1.), Red earth $(900-1,600 \mathrm{~m}$ a.s.1.) and Yellow brown soil (above 1,600 m a.s.l.). However, Lateric red earth is also found as a palaeosol in the Red earth zone. The crystallinity ratio $\left(\mathrm{Fe}_{\mathrm{d}}-\mathrm{Fe}_{\mathrm{o}}\right) / \mathrm{Fe}_{\mathrm{t}}$ of iron was calculated from the results of of chemical analysis for each soils: for Quasi latosol it is over 0.85 in most cases, between 0.7 and 0.85 for Lateritic red earth, and from 0.5 to 0.7 for Red earth.

Based on KIRA's Warmth Index, areas in Xishuangbanna below $900 \mathrm{~m}$ a.s.l. are classified as subtropical, while those above that level belong to the warm temperate zone. But while Red soil is found in the subtropical zone, Yellow brown forest soil as well red soil as palaeosols are widely distributed in the warm temperate zone in Southwest Japan. Thus the relationship between the Warmth Index and the soil type in Yunnan, South China is different from their equivalent in Southwest Japan. However, the iron crystallinity ratio of the Red earth in Yunnan and the Red soil in Southwest Japan lie almost within the same range ( 0.5 to 0.7$)$.

The southern part of Yunnan Province lower than $600 \mathrm{~m}$ a.s.l. is subtropical according to KIRA's Warmth Index, but, Quasi latosol distributes in Xishuangbanna. In this region, $d$ (water deficiency based on THORNTHWAITE's 1948 definition) occurs every year between January and June. Generally, in Guangdong Province, eastern South China, does not occur every year from January to June. In contrast, it occurs annually in August and September in eastern South China. The southern part of Yunnan Province has high temperature with humid climate in summer, a favorable condition for the decomposition of organic matter. On the other hand, winter and spring have mild weather and drought occurs every year. It is believed that this climatic condition encourages the crystallization of iron and as a result, Quasi latosol and Lateritic red earth are distributed even though the thermal condition is subtropical. However, there is still the possibility that Quasi latosol may be distributed as a palaeosol in this area.
\end{abstract}

Key words: Lateritic red earth, Red earth.

\section{INTRODUCTION}

The sourthern part of Yunnan Province is topographically composed of the southernmost part of Hengduan Shan and the adjoining peneplain with altitudes of about $1,300 \mathrm{~m}$ a.s.l. The rivers and their valleys cut into the plateau. Geologically, the area consists of marine sediments of Carboniferous to Permian Palaeozoic origin and of sandstone, which was deposited as a sediment during the Mesozoic to Tertiary peri- ods. The impact of the Himalayan orogenic movement is more pronounced in the western than the eastern parts of Yunnan Province (Chinese Academy of Geological Sciences, 1976). The topography of the study area is shown in Fig. 1, which was made on the basis of Tactical Pilotage Chart issued by U. S. Air Force (1969). In the northwestern half of the area there is a wide expanse of uplifted peneplains ranging in altitude around $1,300 \mathrm{~m}$ a.s.l. At the lowest level from 1,500 to 2,500 feet $(500-800 \mathrm{~m})$ a.s.l. are located river basins. Intermontane basins

\footnotetext{
*Department of Natural Sciences, Komazawa University, Setagaya-ku, Tokyo 154

**Institute of Applied Biochemistry, University of Tsukuba, Tsukuba, Ibaraki 305
} 


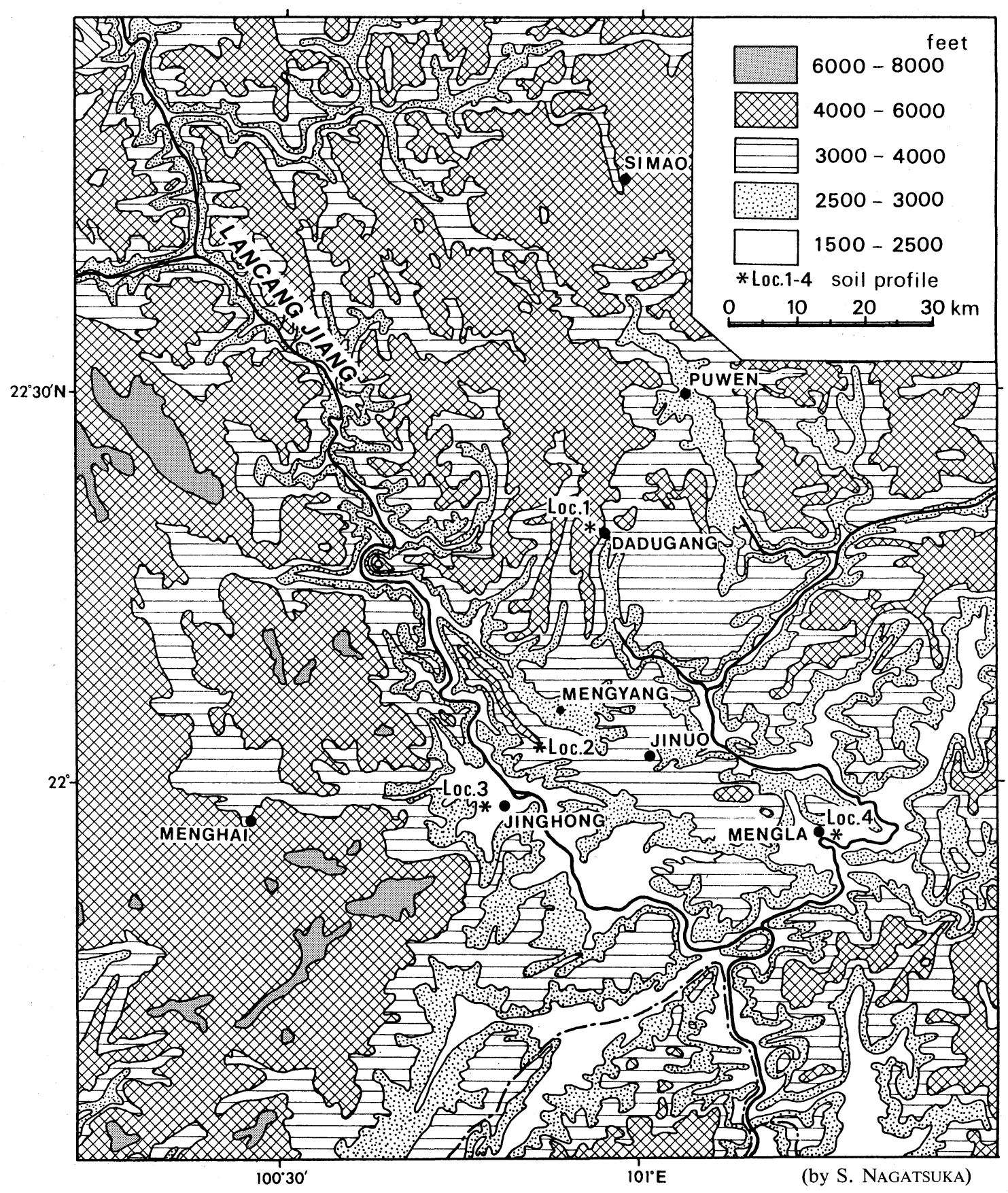

Figure 1. Topographical map of Xishuangbanna.

The locality number shows the place of the soil profile of which chemical analysis is shown in Table 2 . 
such as Simao, Puwen, Mengyang and Menghai are also situated in the study area.

The distribution of natural vegetation in Xishuangbanna shows vertical zonality as follows: tropical monsoon forest $(500-800 \mathrm{~m}$ a.s.l.), montane rain forest $(800-1,000 \mathrm{~m}$ a.s.l.), and monsoonal evergreen broad-leaved forest and Simao pine forest (above $1,000 \mathrm{~m}$ a.s.1.).

In December, 1986 and 1988, we studied the soils in an area extending from Simao through Jinghong and Mengla for two reasons, namely, (a) to identify the properties of soil in Xishuangbanna in the southern part of Yunnan Province and, (b) to compare them with those in Southwest Japan. Hopefully, our study will lead to a better understanding of the relationship between soil types in China and the Red soil in Japan.

\section{CLIMATIC ENVIRONMENTS FOR SOIL FORMATION}

KIRA (1945 a, b) studied the climatic division of East Asia based mainly on vegetaion type and introduced a Warmth Index. His index is derived from values of air temperature accumulated at a place. Specifically, it is obtained by adding together the mean monthly temperature above $5^{\circ} \mathrm{C}$ over the year. According to his study, a tropical zone is classified as a zone with an annual total of more than $240^{\circ} \mathrm{C}$, a subtropical zone $180^{\circ}-240^{\circ} \mathrm{C}$, and a warm temperate zone $85^{\circ}-180^{\circ} \mathrm{C}$.

The altitudinal variations of the Warmth Index in Xishuangbanna, China, and in Southwest Japan including Kyushu and the Nansei Islands, are shown in Fig. 2. Regions lower than $900 \mathrm{~m}$ in both Xishuangbanna and Southwest Japan are subtropical but the zonal soils formed under recent climatic conditions are different in the two areas. While Quasi latosol is found below 600 $m$ a.s.l. in Xishuangbanna and Lateritic red earth between 600 and $900 \mathrm{~m}$, in the Nansei Islands, the equivalent soil type is Red soil. In light of this discrepancy, it is clear that soil formation in the two climatically similar regions cannot be explained solely by the similarity of their Warmth Index.

In this part of the study, the sequence of wet/dry weather is examined since the thermal regime alone cannot explain the distribution of

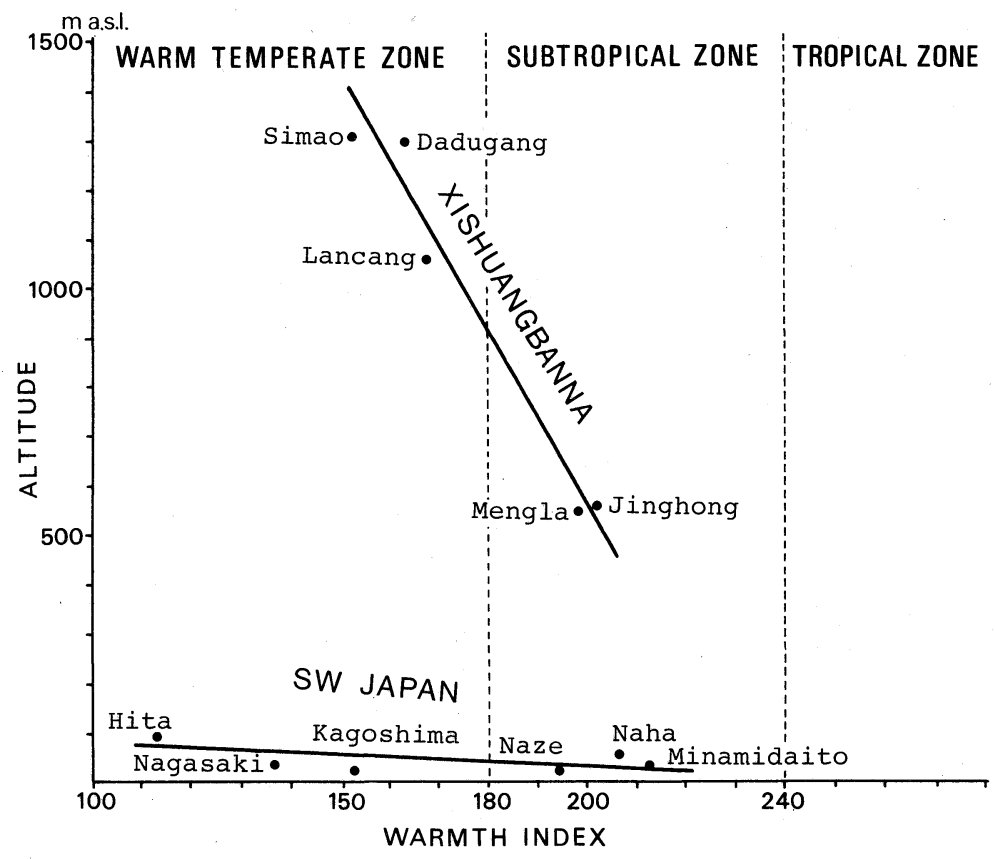

Figure 2. The relationship between Warmth Index and altitude a.s.l. in Xishuangbanna, South China, and Southwest Japan 
soil types in the two regions. URUSHIBARAYoshino (1989) has shown that in the Nansei Islands, a definite relationship exists between drought driven damage to the sugarcane crop and THORNTHWAITE's water deficiency (d). The latter was obtained by setting the maximum water holding capacity of the soil at $100 \mathrm{~mm}$ (Thornthwaite, 1948). In the present study, 100 $\mathrm{mm}$ is also used as a representative figure for the expression of wet/dry conditions. The $d$ values were calculated for every month of each year at stations where data are available (URUSHIBARA, 1980; Yoshino and URUSHIBARA, 1982). The long term monthly means were also calculated. Firstly, it is obvious that water deficiency occurs at stations in Yunnan Province from January to June with a maximum in March. In contrast, in Nanning and Guangzhou in the eastern part of tropical China, $d$ is not very pronounced in the first half of the year. However, it is fairly high in the autumn through to January. Secondly, in the Nansei Islands in most cases, $d$ occurs between May and October inclusive. The $d$ value at Minamidaito Island $\left(31^{\circ} 14^{\prime} \mathrm{E}, 25^{\circ} 50^{\prime} \mathrm{N}\right)$ in the Northwest Pacific is the largest in that area, but still smaller than those found in Yunnan Province. Monthly variations in the values of $d$ and the mean air temperature at the respective stations in South Yunnan and the Nansei Islands are shown in Fig. 3. From this figure, it is seen that occasions of water deficiency in the Nansei Islands occur with a frequency of once in three years. In contrast, $d$ occurs almost annually in Yunnan in those months with a mean air temperature between $15^{\circ}$ and $25^{\circ} \mathrm{C}$. In conclusion, the seasonality of $d$, its frequency and the mean air temperature with which it is associated in location in South China differ from their equivalents in Southwest Japan (Table 1).

From a long term perspective, Yunnan has a clear dry season, mostly longer than six months, and a wet season. Water deficiency does not occur in the warmest months due to high rainfall. Therefore, it is believed that organic matter is dissolved faster in an environment created by the joint occurrence of high humidity and high temperature. Crystallization of iron might occur easily in the dry season in Xishuangbanna where the season is sufficiently long. In contrast, the dry season is less frequent and the spells shorter in
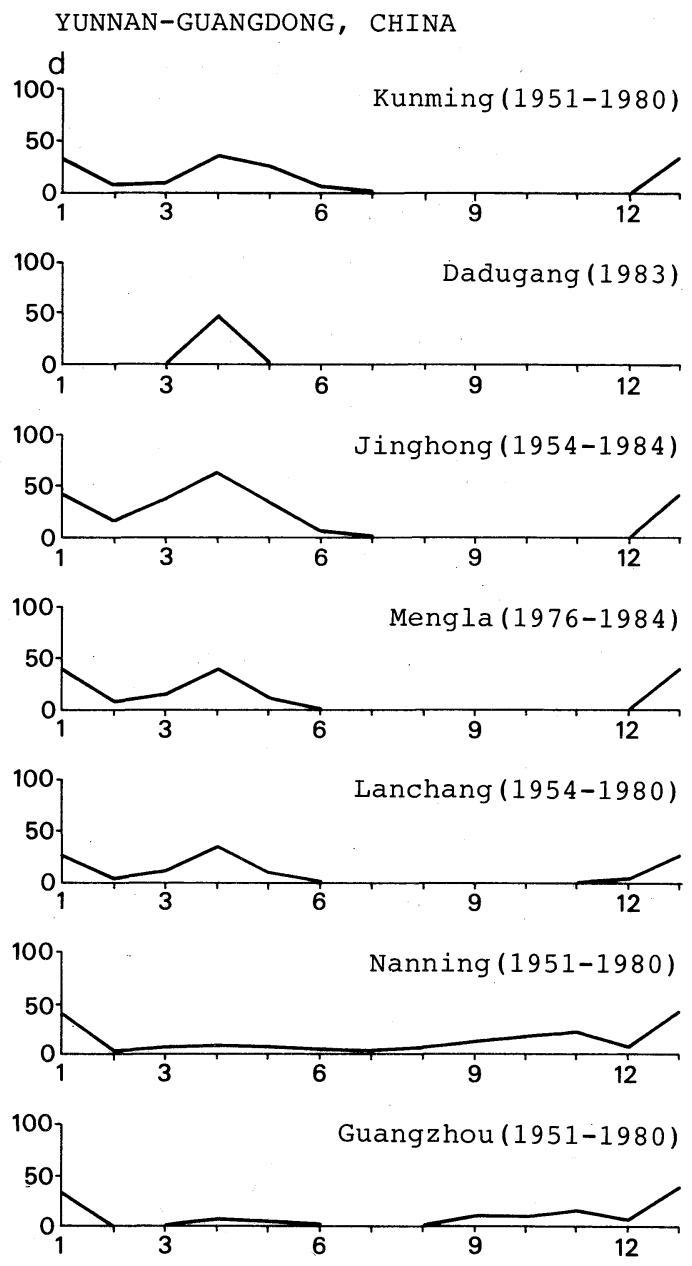

NANSEI ISLANDS, JAPAN
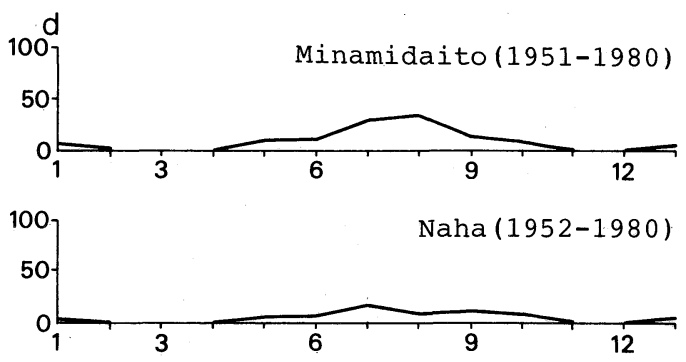

Figure 3. Water deficiency, $\mathrm{d}(\mathrm{mm})$ by year climate in South China and the Nansei-Islands' in Japan

the Nansei Islands than in Xishuangbanna. Such conditions might be unfavorable for the crystallization of iron in the soils. 
Table 1. Comparison of climatic conditions in Xishuangbanna and the Nansei Islands. The d values were calculated for every year by THORNTHWAITE's (1948) method

\begin{tabular}{lll}
\hline \hline & \multicolumn{1}{|c}{$\begin{array}{c}\text { Xishuangbanna } \\
\text { South Yunnan }\end{array}$} & \multicolumn{1}{c}{$\begin{array}{c}\text { Nansei Islands } \\
\text { Southwest Japan }\end{array}$} \\
\hline Month or season that shows d values & $\begin{array}{l}\text { Jan. - June } \\
\text { Mostly every year }\end{array}$ & $\begin{array}{l}\text { Summer or Autumn } \\
\text { Once in three years }\end{array}$ \\
Occurrence frequency & $15^{\circ}-25^{\circ} \mathrm{C}$ & Higher than $25^{\circ} \mathrm{C}$ \\
\hline Monthly mean air temperature when the d values occur & $180^{\circ}-240^{\circ} \mathrm{C}$ & $180^{\circ}-240^{\circ} \mathrm{C}$ \\
\hline Warmth Index
\end{tabular}

\section{CLASSIFICATION AND DISTRIBUTION OF SOILS IN SOUTHERN YUNNAN PROVINCE}

\section{Classification of soils in China}

According to the description provided by Nanjing Institute of Soil Science, Academia Sinica (1978), the south-north distribution of soil types in Yunnan Province is as follows: Latosol (磚紅壤)， Lateritic red earth (赤紅䁃) and Red earth (紅袞) (Fig. 4). Yellow earth (黄壌) occurs in the higher parts of the mountain. The areas occupied by Latosol are limited to the lowland south of $20^{\circ} \mathrm{N}$, where the accumulated temperature $\geq 10^{\circ} \mathrm{C}$ is about $3,500^{\circ} \mathrm{C}$, annual precipitation is $1,800-1,900 \mathrm{~mm}$, and LANG's rain factor is between 82 and 88 . Lateritic Red earth is found in areas lower than $800 \mathrm{~m}$ a.s.l., where the accumulated temperature $\geq 10^{\circ} \mathrm{C}$ is about $7,500^{\circ} \mathrm{C}$, annual precipitation is $1,500-1,700$ $\mathrm{mm}$, and the rain factor is about 75 . Red earth occurs in areas higher than $800 \mathrm{~m}$ a.s.l. The accumulated temperature varies widely in these areas, but annual precipitation is about 1,700 $\mathrm{mm}$ and the rain factor is about 75 . Near Kunming Red earth is found only on flat surfaces in the hills: therefore, it is thought that some of it must be a relic or palaeosol as stated above. The complexity inherent in the distribution of Red earth in this area suggests that factors other than accumulated temperatures should be taken into account when interpretating their distirbution (URUSHIBARA-Yoshino, 1986).

The great soil groups of China are classified according to their zonality, base content, silicaalumina ratio $\left(\mathrm{SiO}_{2} / \mathrm{Al}_{2} \mathrm{O}_{3}\right)$ etc. Based on the silica-alumina ratio, the boundary between
Latosol and Lateritic red earth lies in the 1.5 to 1.7 range; the boundary between Lateritic red earth and Red earth is 2.0; and the boundary between Red earth and Yellow earth is about 2.5 (Nanjing Institute of Soil Science, Academia Sinica, 1978). The soil distribution in the southern part of Yunnan Province was reported to have a general vertical zonality of: Latosols $(500-800$ $\mathrm{m}$ a.s.l.), Lateritic red earth $(800-1,000 \mathrm{~m}$ a.s.1.), Red earth or Yellow red earth $(1,000-1,500 \mathrm{~m}$ a.s.l.) and Yellow brown earth (above 1,500 $\mathrm{m}$ a.s.1.) (ZHUO, 1983). It is reported that the soils in the Xishuangbanna Natural Reserve distribute sequentially as follows: Typo chrult (磚紅塎) $(600-900 \mathrm{~m})$, Lateritic red soil $(900-1,600 \mathrm{~m})$ and Mountain red soil (山地紅壤) (more than 1,600 m) (WANG et al., 1987). But this result does not coincide with our result which is shown in the following chapter.

\section{Soil properties and the distribution of soils in Xishuangbanna}

The vertical soil distribution in Xishuangbanna based on our research is" shown in Fig. 5. Quasi latosol is distributed at altitudes below $600 \mathrm{~m}$ a.s.l. in valleys occupied by tropical forests. Lateritic red earth occurs at altitudes between 600 $\mathrm{m}$ and $900 \mathrm{~m}$ a.s.l., where the vegetaion is transitional from the tropical semievergreen monsoonal forest to the monsoonal evergreen broad-leaved forest. Red earth prevails from 900 $\mathrm{m}$ to about $1,600 \mathrm{~m}$ a.s.1. Here the vegetaion is warm temperate (lucidophyllous) forest. Finally Lateritic red earth occurs as a palaeosol in the Red earth zone (NAGATSUKA and URUSHIBARAYoshino, 1988 a). The distribution of Quasi latosol seems to us to be as a present soil at the present stage. But the possibility of it being as a palaeosol also cannot be denied. We have to 


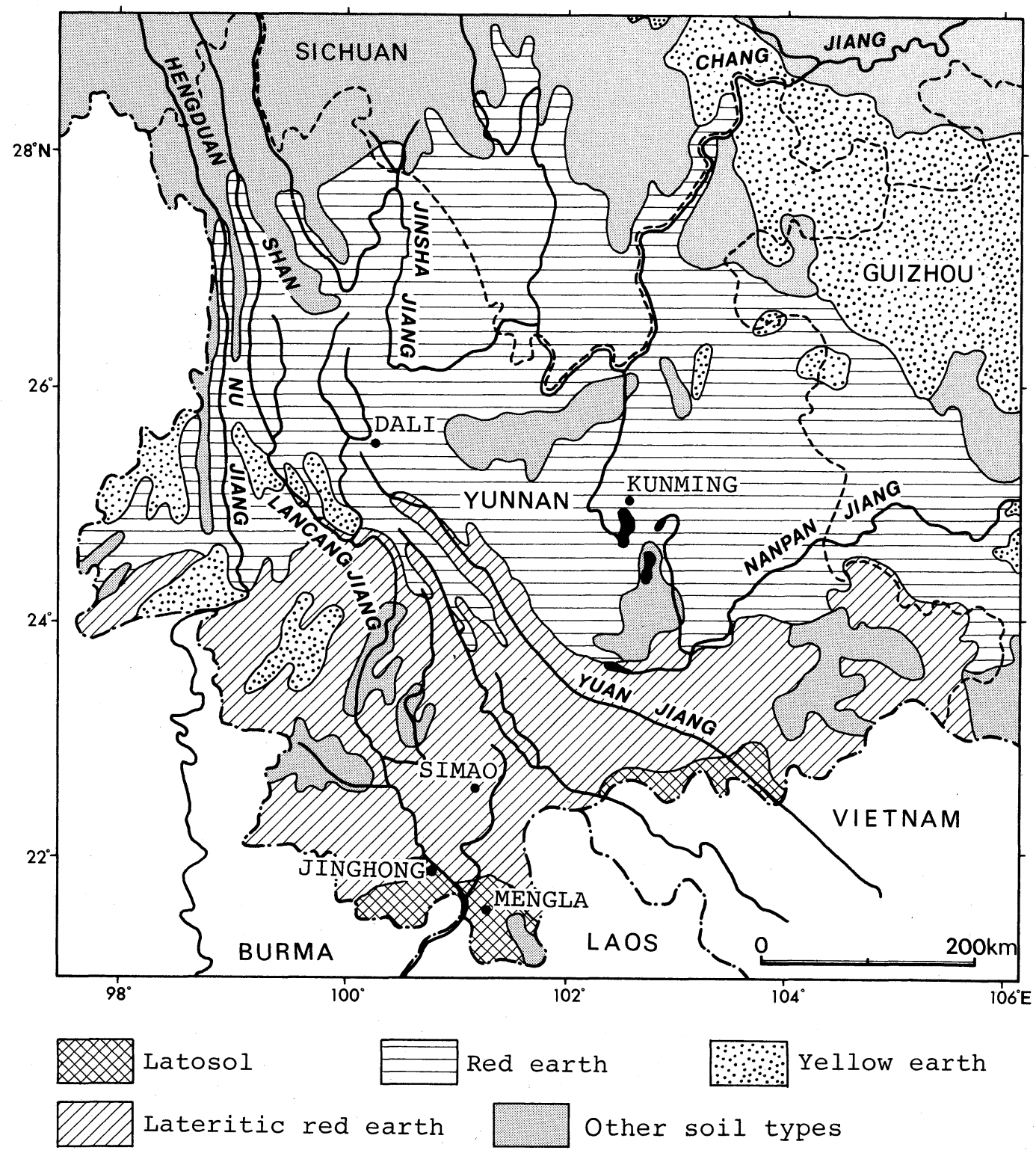

Figure 4. Soil map of South China (by Nanjing Institute of Soil Science, Academia Sinica, 1978)

study the detail of this point in the field. According to the results, we shall discuss the matter in the near future.

Soil samples collected at typical soil profiles in Xishuangbanna were sent to the Nanjing Institute of Soil Science, Academia Sinica for chemical analysis. The soil profiles have described by
NAGATSUKa and URUShibara-Yoshino (1988 a, b). The results of chemical analysis are shown in Table 2 . The table, clearly indicates that the $\mathrm{CEC}$ of the B-horizon is relatively small at Mengla and Jinghong. The crystallinity ratio $\left(\mathrm{Fe}_{\mathrm{d}^{-}}\right.$ $\left.\mathrm{Fe}_{\mathrm{o}}\right) / \mathrm{Fe}_{\mathrm{t}}$ of iron is different from soil type to soil type as shown in Fig. 6. Specifically, the crys- 


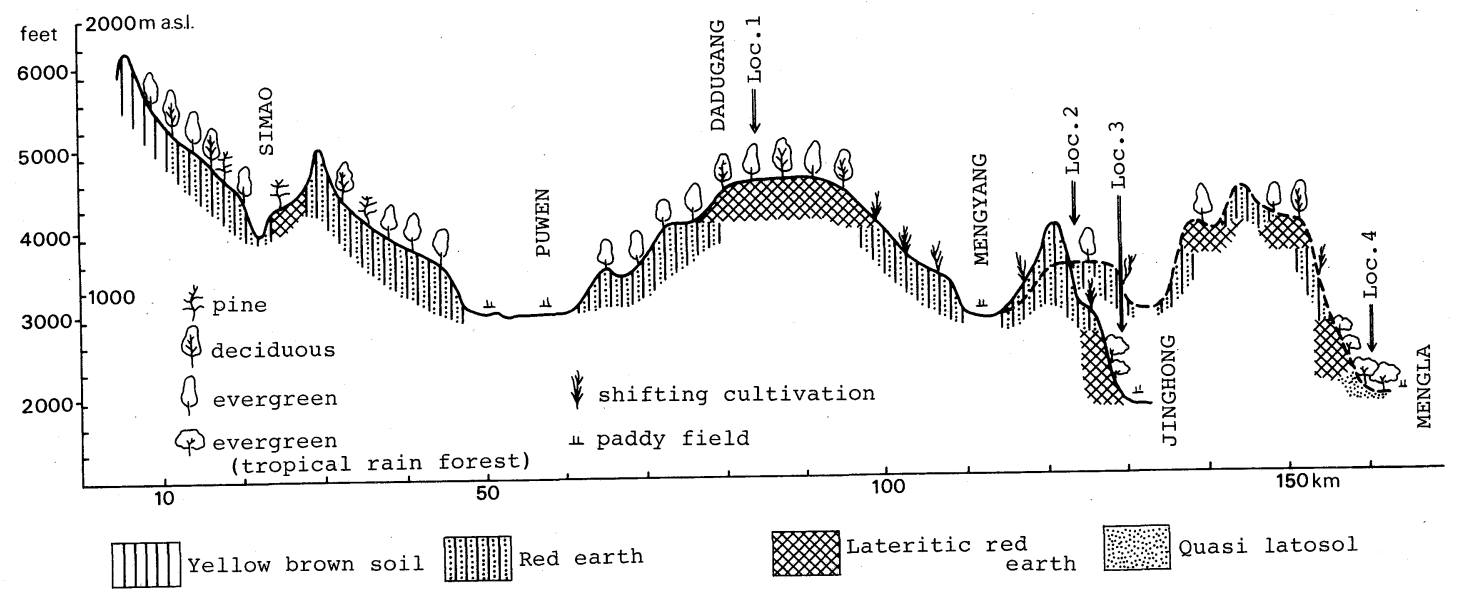

Figure 5. The relationship between soil distribution and topography in Xishuangbanna

Table 2 Results of chemical analyses at the typical profiles in Xishuangbanna, Yunnan Province

\begin{tabular}{|c|c|c|c|c|c|c|c|c|c|c|c|c|c|c|c|c|}
\hline \multirow{2}{*}{ Location } & \multirow{2}{*}{ Horizon } & \multirow{2}{*}{ Depth } & \multicolumn{2}{|c|}{$\mathrm{pH}$} & \multirow{2}{*}{$\begin{array}{l}\text { CEC } \\
\text { (me/ } \\
100 \mathrm{~g})\end{array}$} & \multicolumn{5}{|c|}{$\begin{array}{c}\text { Exchangeable base } \\
(\mathrm{me} / 100 \mathrm{~g})\end{array}$} & \multirow{2}{*}{$\begin{array}{l}\text { Base- } \\
\text { sat. } \\
(\%)\end{array}$} & \multicolumn{3}{|c|}{$\mathrm{Fe}_{2} \mathrm{O}_{3}$} & \multirow{2}{*}{$\frac{\mathrm{Fe}_{\mathrm{o}}}{\mathrm{Fe}_{\mathrm{d}}}$} & \multirow{2}{*}{$\frac{\left(\begin{array}{c}\mathrm{Fe}_{\mathrm{d}} \\
\left.\mathrm{Fe}_{\mathrm{o}}\right)\end{array}\right.}{\mathrm{Fe}_{\mathrm{t}}}$} \\
\hline & & & $\mathrm{H}_{2} \mathrm{O}$ & $\mathrm{KCl}$ & & $\mathrm{Ca}$ & $\mathrm{Mg}$ & $\mathrm{K}$ & $\mathrm{Na}$ & Total & & $\mathrm{Fe}_{\mathrm{t}}$ & $\mathrm{Fe}_{\mathrm{d}}$ & $\mathrm{Fe}_{\mathrm{o}}$ & & \\
\hline \multirow{8}{*}{$\begin{array}{l}\text { Locality } 1 \\
\text { Dadugang } \\
(1,330 \mathrm{~m} \\
\text { a.s.l. })\end{array}$} & $A_{11}$ & $0-10$ & 5.50 & 4.44 & 15.24 & 4.73 & 1.74 & 0.30 & 0.15 & 6.92 & 45.4 & 3.57 & 2.98 & 0.39 & 0.13 & 0.73 \\
\hline & $A_{12}$ & $10-20$ & 5.11 & 4.03 & 13.45 & 1.33 & tr. & 0.17 & 0.12 & 1.62 & 12.0 & 4.03 & 3.64 & 0.31 & 0.09 & 0.83 \\
\hline & $\mathrm{B}_{1}$ & $20-35$ & 4.84 & 4.01 & 11.40 & 0.04 & tr. & 0.12 & 0.06 & 0.22 & 1.9 & 4.71 & 3.78 & 0.30 & 0.08 & 0.74 \\
\hline & $\mathrm{B}_{2}$ & $35-60$ & 4.93 & 3.98 & 10.80 & 0.16 & tr. & 0.10 & 0.08 & 0.34 & 3.1 & 4.91 & 3.98 & 0.29 & 0.07 & 0.75 \\
\hline & $\mathrm{B}_{3}$ & $60-80$ & 5.09 & 4.10 & 9.34 & 0.14 & tr. & 0.10 & 0.09 & 0.33 & 3.5 & 5.47 & 3.98 & 0.23 & 0.06 & 0.69 \\
\hline & $\mathrm{C}_{\mathrm{g}}$ & $80-140$ & 4.92 & 4.22 & 7.42 & 0.08 & tr. & 0.10 & 0.06 & 0.24 & 3.2 & 5.42 & 4.15 & 0.24 & 0.06 & 0.72 \\
\hline & IIB $^{\mathrm{g}}$ & $140-215$ & 5.14 & 4.23 & 6.89 & 0.44 & tr. & 0.10 & 0.11 & 0.65 & 9.4 & 5.95 & 3.90 & 0.19 & 0.55 & 0.62 \\
\hline & $\mathrm{IIC}_{1}$ & $215-235$ & 5.09 & 4.28 & 8.28 & 1.90 & 0.32 & 0.30 & 0.08 & 2.60 & 31.4 & 5.21 & 3.98 & 0.20 & 0.05 & 0.73 \\
\hline \multirow{5}{*}{$\begin{array}{l}\text { Locality } 2 \\
\text { Mengyang } \\
(1,090 \mathrm{~m} \\
\text { a.s.l. })\end{array}$} & $A_{1}$ & $0-\quad 7$ & 5.38 & 4.13 & 30 & 3.35 & 4.61 & 0.59 & 0.15 & 8.70 & ד.7. & 9.26 & 5.86 & 0.42 & 0.07 & 0.59 \\
\hline & $\mathrm{B}_{1}$ & $7-20$ & 5.25 & 3.96 & 15.88 & 1.21 & 5.17 & 0.49 & 0.12 & 6.99 & 44.0 & 9.26 & 6.08 & 0.36 & 0.06 & 0.62 \\
\hline & $\mathrm{B}_{2}$ & $20-60$ & 5.14 & 3.94 & 15.15 & 0.89 & 5.05 & 0.37 & 0.22 & 6.53 & 43.0 & 9.67 & 6.84 & 0.32 & 0.05 & 0.67 \\
\hline & IIB $_{2 t}$ & $60-85$ & 5.05 & 3.98 & 13.52 & 0.32 & 1.09 & 0.27 & 0.15 & 1.83 & 13.5 & 8.46 & 6.84 & 0.32 & 0.05 & 0.77 \\
\hline & $\mathrm{IIC}_{1}$ & $85-145$ & 5.07 & 3.98 & 13.78 & 0.32 & 0.52 & 0.23 & 0.11 & 1.18 & 8.6 & 9.26 & 7.06 & 0.35 & 0.05 & 0.72 \\
\hline \multirow{7}{*}{$\begin{array}{l}\text { Locality } 3 \\
\text { Jinghong } \\
\text { ( } 570 \mathrm{~m} \\
\text { a.s.l.) }\end{array}$} & $\mathbf{A}_{1}$ & $0-5$ & 5.52 & 4.69 & 11.00 & 2.42 & 1. & 0.70 & 1.16 & 6.22 & 56.5 & 4.38 & 3.46 & 0.28 & 0.08 & 0.73 \\
\hline & $\mathrm{B}_{1}$ & $5-20$ & 5.01 & 4.05 & 8.94 & 0.16 & 0.53 & 0.38 & 0.06 & 1.13 & 12.6 & 4.60 & 3.72 & 0.26 & 0.07 & 0.75 \\
\hline & $\mathrm{B}_{2}$ & $20-75$ & 5.10 & 4.01 & 9.41 & 0.12 & 0.24 & 0.35 & 0.12 & 0.83 & 8.8 & 5.49 & 4.29 & 0.22 & 0.05 & 0.74 \\
\hline & $\mathrm{B}_{3 \mathrm{cn}}$ & $75-95$ & 5.27 & 4.04 & 9.61 & 0.20 & 0.12 & 0.27 & 0.22 & 0.81 & 8.4 & 5.58 & 4.43 & 0.20 & 0.05 & 0.76 \\
\hline & $\mathrm{C}_{1 \mathrm{cn}}$ & $95-128$ & 5.16 & 4.02 & 8.88 & 0.24 & tr. & 0.21 & 0.06 & 0.51 & 5.7 & 5.51 & 4.29 & 0.18 & 0.04 & 0.75 \\
\hline & $\mathrm{C}_{2 \mathrm{cn}}$ & $128-170$ & 5.06 & 4.03 & 9.47 & 0.32 & 0.08 & 0.19 & 0.06 & 0.65 & 6.9 & 5.32 & 4.13 & 0.16 & 0.04 & 0.75 \\
\hline & $\mathrm{C}_{3 \mathrm{cn}}$ & $170-200$ & 5.19 & 3.98 & 8.68 & 0.12 & 0.24 & 0.17 & 0.09 & 0.62 & 7.1 & 5.32 & 4.04 & 0.15 & 0.04 & 0.73 \\
\hline \multirow{6}{*}{$\begin{array}{l}\text { Locality } 4 \\
\text { Mengla } \\
(550 \mathrm{~m} \\
\text { a.s.l.) }\end{array}$} & $\mathbf{A}_{1}$ & $0-6$ & 5.84 & 5.37 & 19.15 & 13.17 & 3.19 & 0.27 & 0.27 & 16.90 & 88.3 & 5.21 & 4.70 & 0.28 & 0.06 & 0.85 \\
\hline & $\mathrm{B}_{1}$ & $6-32$ & 4.64 & 3.70 & 10.80 & 0.48 & 0.20 & 0.08 & 0.16 & 0.92 & 8.5 & 5.95 & 5.26 & 0.38 & 0.07 & 0.82 \\
\hline & $\mathrm{B}_{2}$ & $32-57$ & 4.67 & 3.79 & 10.73 & 1.25 & 0.12 & 0.11 & 0.08 & 1.56 & 14.5 & 7.19 & 6.45 & 0.25 & 0.04 & 0.86 \\
\hline & $\mathrm{IIB}_{2}$ & $57-105$ & 4.62 & 3.90 & 9.34 & 0.16 & 0.04 & 0.06 & 0.15 & 0.41 & 4.4 & 7.68 & 7.20 & 0.10 & 0.01 & 0.92 \\
\hline & $\mathrm{IIC}_{1}$ & $105-106$ & 4.55 & 3.99 & 5.70 & 0.20 & 0.32 & 0.04 & 0.06 & 0.62 & 10.9 & 6.96 & 6.55 & 0.07 & 0.01 & 0.93 \\
\hline & $\mathrm{IIC}_{2}$ & $160-185$ & 4.59 & 4.08 & 4.64 & 0.16 & 0.24 & 0.04 & 0.06 & 0.50 & 10.8 & 5.84 & 5.35 & 0.07 & 0.01 & 0.90 \\
\hline
\end{tabular}




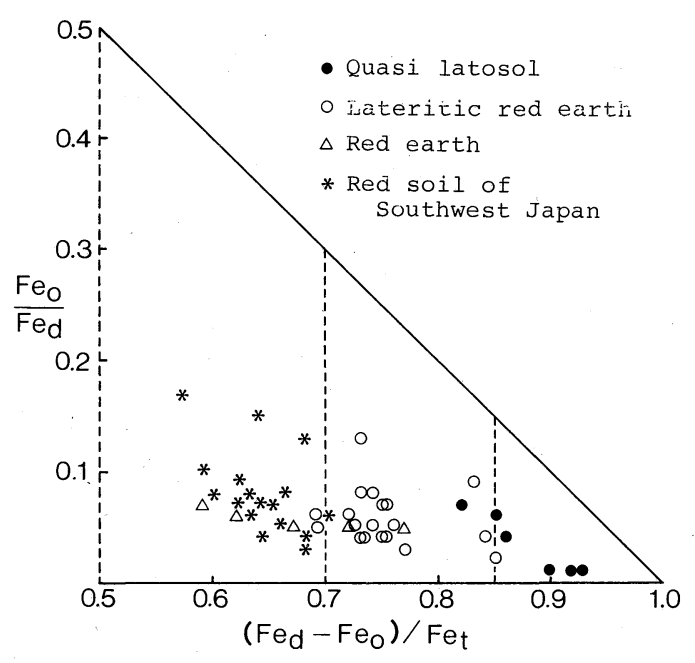

Figure 6. Activity and crystallinity ratios of iron oxides in Xishuangbanna and Southwest Japan.

tallinity ratio of iron in Quasi latosol is more than 0.85 in most cases, 0.7 to 0.85 in Lateritic red earth and 0.5 to 0.7 in Red earth. Exceptions are as follows: A horizon of Quasi latosol shows below 0.85 , and II horizons of Red earth show higher than 0.7 .

The distribution of zonal soils in Southwest Japan is as follows: Yellow brown forest soil north of Kyushu, Red soil in wet subtropical broad-leaved evergreen forest south of the Amami-Gunto in the Nansei Islands. The grade of the red color in the $\mathrm{B}$ horizon is believed to be related to the difference in the stage of development of the rubefaction process. The grade is classified by the activity ratio $\left(\mathrm{Fe}_{\mathrm{o}} / \mathrm{Fe}_{\mathrm{d}}\right)$ of free iron oxide and the crystallinity ratio given above. Thus, in the domain of Red soil, the activity ratio is $<0.4$, and crystallinity ratio $>0.5$, even if the $\mathrm{B}$ horizon is yellow. The base saturation of, Yellow brown forest soil varies with parent rocks, though the activity ratio is still $<0.4$, and the crystallinity ratio $>$ (NAGATSUKA, 1972, 1975). In the region with Yellow brown forest soil and north of it, the Red soil occurs as a palaeosol on the terraces formed in the last interglacial period (about 130,000 years B. P.) and earlier.

The crystallinity ratio of iron in Japan's Red soil range primarily between 0.5 to 0.7 . Because it is Red soil, the values of the crystallinity ratio of iron of Red earth in South China are the same as Red soil in Southwest Japan. However, the climatic conditions of the areas in which Red soils are found in Southwest Japan are different from those prevailing in Xishuangbanna in Yunnan Province. The two areas are compared using KIRA's Warmth Index accumulated monthly mean temperature over $5^{\circ} \mathrm{C}$ (UrushibaraYoshino, 1988). The comparison between soils and Warmth Index of both areas is shown in Table 3.)

\section{CONCLUSION}

i) By comparing the climatic conditions in Xishuangbanna, Yunnan Province, South China, and the Nansei Islands, Southwest Japan, the following facts were found. Both regions experience similar thermal conditions as expressed by KIRA's Warmth Index, but have different dry/wet sequences as expressed by the $d$ factor (water deficiency calculated by THORNTHWAITE's method). Specifically, in Xishuangbanna, water deficiency (dry season) occurs over a longer period (six months) and with similar intensity almost annually in those months with mean air temperature of $15^{\circ}-25^{\circ} \mathrm{C}$. In contrast, in the Nansei Islands, the dry season is shorter and its frequency lower. Moreover, it occurs in the months with mean air temperature higher than $25^{\circ} \mathrm{C}$. The conditions in Xishuangbanna are thought to be favorable for the crystallization of iron and as

Table 3 Warmth index and soil distribution in Xishuangbanna and Southwest Japan

\begin{tabular}{lll}
\hline \multicolumn{1}{c}{ Warmth Index } & \multicolumn{1}{c}{$\begin{array}{l}\text { Xishuangbanna in } \\
\text { Yunnan Province }\end{array}$} & \multicolumn{1}{c}{ Southwest Japan } \\
\hline Subtropical zone $\left(180^{\circ} \mathrm{C}-240^{\circ} \mathrm{C}\right)$ & $\begin{array}{l}\text { Quasi latosol } \\
\text { Lateritic red earth } \\
\text { Red earth (as a palaeosol, } \\
\text { Lateritic red earth) }\end{array}$ & $\begin{array}{l}\text { Yellow brown forest soil } \\
\text { (as a palaeosol, Red soil) }\end{array}$ \\
\hline
\end{tabular}


a result, Quasi latosol (tropical soil) and Lateritic red earth are formed in that area.

ii) The crystallinity ratio $\left(\mathrm{Fe}_{\mathrm{d}}-\mathrm{Fe}_{\mathrm{o}}\right) / \mathrm{Fe}_{\mathrm{t}}$ of iron was used for the classification of soils. The ratio for Quasi latosol is over 0.85 , between 0.7 and 0.85 for Lateritic red earth, and from 0.5 to 0.7 for Red earth. In Xishuangbanna, these soil types are distributed as vertical zonal soils; Quasi latosol (below $600 \mathrm{~m}$ a.s.1.), Lateritic red earth (600-900 m a.s.1.)8, Red earth (900 - 1,600 m a.s.1.).Lateritic Red earth is distributed as a palaeosol on the stable peneplain in the red earth zone. But, there is the possibility that Quasi latosol may be distributed as a palaeosol in the study area.

\section{Acknowledgements}

This is a part of the results of a joint study between Japan and China supported by the Ministry of Education, Science and Culture in Japan (Leader: M. YosHINO, Nos. 61041012, 62043011 and 63041025). We express our sincere thanks to Prof. XI Cheng-fan, Nanjing Institute of Soil Science and his colleagues for the chemical analysis of the soil samples.

(Received Oct. 14, 1989)

(Accepted Jan. 15, 1990)

\section{References}

Chinese Academy of Geological Sciences (1976): Geological Map of People's Republic of China, 1:4,000,000. (in Chinese)

KIRA, T. (1945 a): A new classification of climate in Eastern Asia as the basis for agricultural geography. Hort. Inst. Kyoto Univ., Kyoto, 23 P. (J)

KIRA, T. (1945 b): New classification of climate in Southeast Asia and the Western Pacific. Hort. Inst. Kyoto Univ., Kyoto. (J)

NAgAtsuKa, S. (1972): Studies on genesis and classification of soils in warm-temperate region of Southwest Japan, Part 3. Some features in distribution and mode of existence of free iron and aluminium oxides in the soil profile. Soil Sci. Plant Nutr. 18 (4), 147-154.

NAGATSUKA, S. (1975): Genesis and classification of Yellow-brown forest soils and Red soils in Southwest Japan. Bull. National Inst. Agricultural Sciences, B(26) $133-257$. (JE)

NAGATSUKA, S. and URUSHIBARA-Yoshino, K. (1988 a): Climatic conditions and distribution of soils in Yunnan, South China. The Tropical Environment, University of Calgary, Canada, 9-14.

NAGATSUKA, S. and URUSHIBARA-Yoshino, K. (1988 b): On the vertical zonality of soil distribution and soil conditions in Xihuangbanna, South Yunnan. Climatological Notes, 38, 229-247.

Nanjing Institute of Soil Science, Academia Sinica (1978): Soils of China, Science Press, Beijing, 729 p. (in Chinese)

Thornthwaite, C. W. (1948): An approach toward a rational classification of climate. Geogr. Rev, 38-1, 55-94.

URUSHIBARA, K. (1980): The year climates by the climatic types of Köppen and Thornthwaite on the Nansei Islands in Japan. Ann. Tohoku Geogr. Ass., 32-3 110-119. (JE)

URUSHIBARA-YoSHINO, K. (1986): Soil and its utilization for rubber cultivation in South China. Climatological Notes, 35, $211-222$.

URUSHIBARA-YOSHINO, K. (1988): Seasonal variation of dryness and its relation to soil formation. The Tropical Environment, University of Calgary, Canada, 15-19.

URUSHIBARA-YoshinO, K. (1989): The red soils on a limestone area in Nansei Islands, southwest Japan. Proceedings of the International Geographical Union, Study Group Man's Impact on Karst, 183 - 189, (Australia, in Aug., 1988).

U. S. Air Force (1969): Tactical Pilotage Chart.

WANG, Jiayu et al. (1987): An investigation report on soil in Xishuangbanna nature reserve. In: Monographs of Integrated Survey of Xishuangbanna Natural Conservation Region. Kunming, 539 p., 58-87. (in Chinese with English abstract)

Yoshino, M. and URUSHIBARA, K. (1982): Interannual variation of water deficiency over East Asia. Sci. Rep. Inst. Geosci., Univ. Tsukuba, Sec. A, 3, 39-66.

ZHUO, L. (1983): Characteristics and zonality of soil distribution in Yunnan Province. Mountain Research, 1-4, 31-38. (in Chinese) 


\title{
雲南南部における気候条件と土䁃分布の垂直成帯性
}

\author{
漆原和 子*, 永塚鎮 男**
}

雲南省の西双版納には成帯性土壤が垂直的に分布して いる。すなわち 標高 $600 \mathrm{~m}$ ま ま゙は準ラトソル（準磚紅 壤), $600 \mathrm{~m}$ から $900 \mathrm{~m}$ までは赤紅塨, $900 \mathrm{~m}$ から 1600 $\mathrm{m}$ までは赤色土(紅壤), $1600 \mathrm{~m}$ 以高には黄褐色森林土 (黄标㙵) と思われる土壤が分布する。しかし, 赤紅潩は 紅壤の分布地域に古土壤として分布している。鉄の結晶 化指数 $\left(\mathrm{Fe}_{d}-\mathrm{Fe}_{0}\right) / \mathrm{Fe}_{\iota}$ はそれぞれの土壤の化学分析值 から計算した。準磚紅壤の結晶化指数は汪とんどが 0.85 以上の值を示し, 赤紅㙵は $0.7 \sim 0.85$, 紅壤は 0.5 から 0.7 の值を示す。

吉良の暖かさの指数による区分では, 西双版納の標高 $900 \mathrm{~m}$ までは亜熱帯, それより高地は温暖帯である。一 方, 日本では赤色土の分布は西南日本の亜熱帯地域で, 黄褐色森林土は西南日本の温暖帯に広く分布し, かつ古 土壤として赤色土を伴なう。このように西南日本と中国 南部の雲南では, 土壤型と暖かさの指数の間の関係は同
じではない。しかしながら雲南の紅塞と西南日本の赤色 土とは鉄の結晶化指数はほとんど同じ巾（0.5 から 0.7） の中に拉さまる。

標高 $600 \mathrm{~m}$ よりも低い雲南省の南部は吉良の暖かさの 指数では亜熱帯であるが，準磚紅鎧が西双版納にある。 この地方では 1 月から 6 月までの間, 毎年水不足量 $(d)$ が出現する。雲南省から広東省にかけて, 水不足量は毎 年 1 月から 6 月までは出現しない。むしろ水不足量は中 国南部のより東部では 8 月， 9 月に年々出現する。雲南 省の南部は夏に高温湿潤であり, 有機物の分解には好適 である。一方，冬から春にかけて毎年温暖で，かつ乾燥 している。このような気候条件は鉄の結晶化を促進さ せ，結果的に亜熱帯のよらな温度条件であっても準磚紅 壤や赤紅壌を分布させていると考える。ただし，準磚紅 壌はこの調查地域では古土壌として分布している可能性 がある。

干154 東京都世田谷区駒沢, 駒沢大学自然科学教室

** 干305 茨城県つくば市, 筑波大学応用生物化学系 